\title{
Leptospirosis at human-animal-environment interfaces in Latin-America: drivers, prevention, and control measures
}

\author{
Leptospirosis en la interfaz humano-animal-ambiente en América Latina: determinantes, \\ medidas de prevención y control
}

\begin{abstract}
Guadalupe López-Robles ${ }^{1}$, Francisca Nilza Córdova-Robles ${ }^{2}$, Edgar Sandoval-Petris ${ }^{3}$, Maricela Montalvo-Corral2*
Departamento de Agricultura y Ganadería, Universidad de Sonora. Carr. Bahía de Kino Km. 21, 305, Hermosillo Sonora, México.

2 Centro de Investigación en Alimentación y Desarrollo, A.C. Calle Gustavo Astiazarán Rosas, 83304, Hermosillo Sonora, México.

Departamento de Investigaciones Científicas y Tecnológicas, Universidad de Sonora. Blvd. Luis Donaldo Colosio s/n, 83000, Hermosillo Sonora, México.
\end{abstract}

\section{ABSTRACT}

Leptospirosis is one of the main re-emerging zoonotic diseases with a worldwide distribution, mainly in regions with hot or tropical climates. It is caused by the spirochetal bacteria of the genus Leptospira, which, in their pathogenic life forms, causes asymptomatic to severe infections in humans and animals. Animal-to-human transmission occurs most frequently in occupationally exposed groups and in travelers. However, leptospirosis also represents a disease associated with poverty and low sanitation environments, in rural and urban communities, in close contact with companion animals and livestock. A search was performed in PubMed, Scopus, Web of Science and Google scholar databases using query terms related to Leptospira/eptospirosis, reported during 1990-2020. This review focuses on the description of biologic and socioenvironmental drivers that influence the occurrence of the disease in humans. Leptospirosis is found at the human-animal-environment interfaces, and represents a challenge for public and animal health, and food production; hence, improving the strategies for prevention control and surveillance in Latin-American countries is critical, as one of the regions most affected by the disease.

Key words: Leptospirosis, human-animal-environment interfaces, drivers of occurrence, Latin-America.

\section{RESUMEN}

La leptospirosis es una de las principales enfermedades zoonóticas de distribución mundial, principalmente en regiones con climas cálidos o tropicales. Es ocasionada por la espiroqueta del género Leptospira, se presenta clínicamente de forma asintomática, con cuadros moderados o graves en humanos y animales. La transmisión de animal a humanos es más frecuente en grupos ocupacionalmente expuestos como trabajadores agrícolas y ganaderos, veterinarios, cazadores, trabajadores de rastros e incluso viajeros. Asimismo, también representa una enfermedad asociada a pobreza y ambientes de bajo saneamiento, en comunidades rurales y urbanas, en contacto cercano con animales domésticos y ganado. Se realizó una búsqueda en bases de datos de PubMed, Scopus, Web of Science y Google scholar, usando palabras

*Autor para correspondencia: Maricela Montalvo Corral

Correo electrónico: maricela.montalvo@ciad.mx

Recibido: 7 de abril de 2021

Aceptado: 10 de junio de 2021 claves Leptospira/leptospirosis en el periodo 1990-2020. La revisión se enfoca en la descripción de determinantes biológicos y socioambientales que influyen en la ocurrencia de la enfermedad en humanos. La leptospirosis se encuentra en la interfase de la salud humana y animal, y representa un reto para la salud pública, animal, y la producción de alimentos; por lo que es crítica la mejora en las estrategias de prevención, control y vigilancia en países de Latinoamérica, una de las regiones más afectadas por la enfermedad.

Palabras clave: Leptospirosis, interfaz humano-animalambiente, determinantes de ocurrencia, Latinoamérica.

\section{INTRODUCTION}

The current SARS-CoV-2 pandemic is the latest example of the importance of zoonotic diseases, which are those transmitted from animals to humans, and are estimated to cause around $70 \%$ of human infectious diseases (Jones et al., 2008). Zoonoses, occur at human-animal-environment interfaces, thus highlighting the relevance of a One-health approach. Leptospirosis, caused by spirochetal bacteria of the Leptospira genus, is considered the most widely distributed zoonotic disease on the planet (Samsudin et al., 2018). Leptospira has been isolated in many vertebrate taxa, including mammals, birds, amphibians, reptiles, and fish (Viera et al., 2018; Cilia et al., 2021), and has shown genetic heterogeneity. Leptospirosis represents a disease associated with poverty and low sanitation environments, both in rural and urban communities, as well as in livestock production areas, where close interaction with animals could favor the leptospirosis spread. It is also considered an occupational risk disease that affects persons who have contact with infected animals such as agricultural, livestock, meat, abattoir, and rice field workers, veterinarians, hunters, wild animals caretakers, and farmers (Richard and Oppliger, 2015; Bierque et al., 2020).

It has been demonstrated that chronic leptospirosis can cause disability and significant economic losses. However, the infection can be confused with other febrile diseases such as dengue or influenza, due to its symptoms, and if not treated in time it could be lethal (Velasco-Castrejón et al., 2009). Nowadays, leptospirosis is endemic in many areas

Volumen XXIII, Número 3 
and causes significant outbreaks after flooding events, it is a neglected disease not included in many infectious disease surveillance programs in humans and even less in animals. It is estimated that this infection is one of the main causes of economic losses related to livestock, causing reproductive problems in cattle, representing a potential agri-food vulnerability problem due to its impact on livestock production (Ellis, 2015; González and Macías, 2017; Garba et al., 2018).

Due to complex interaction in the ecology and epidemiology of the disease, and multiple animal host and human conditions in urban and rural settlements, it is important to identify the drivers and risk factors that promote infection in exposed people. Leptospirosis has a variable distribution worldwide, with Latin-America as one of the most affected regions (Schneider et al., 2017). We reviewed research articles in databases (PubMed, Scopus, Web of Science and Google scholar, published from 1990 to 2020), using query terms related to leptospirosis/Leptospira biological and socioenvironmental drivers that influence its occurrence in Latin-America. South America is the most affected region, but also an increasing incidence in other latitudes is evident. Well established surveillance programs to identify serovars circulation, including animals, vaccination use and human behavioral interventions, are identified as important measures that will serve as a basis for the design of appropriate interventions to prevent and control the disease in humans and animals.

\section{Leptospirosis \\ Etiological agent and taxonomic classification}

Leptospirosis is a zoonotic disease caused by bacteria commonly known as leptospires. The word has its roots in the Greek leptos meaning thin and the Latin spira that means rolled (Levett and Haake, 2014). Leptospires are gram-negative bacteria that have lipopolysaccharide (LPS) in the outer membrane, a cell wall with peptidoglycan, and an inner membrane (Cameron, 2015). They are spirochetes of the order Spirochaetales, belonging to the family Leptospiraceae within which three genera are included, Leptospira, Turneriella and Leptonema (Levett, 2015). These organisms are differentiated by their guanine and cytosine content (GC), their 16 s ribosomal RNA sequences and their DNA homology. The above allows classifying them in genres. Leptospira has a GC content of 33-43\%, Leptonema $54 \%$ and Turneriella $53.6 \%$ (Yasuda et al., 1987; Stackebrandt et al., 2013).

The Leptospira species have similarity in their morphology, structure and size (Levett, 2015). They have a spiral shape with ends similar to a hook, giving it the appearance of a question mark. They have a length of $6-20 \mu \mathrm{m}$ and a diameter of $0.1 \mu \mathrm{m}$, as well as a wavelength of $0.5 \mu \mathrm{m}$. Pathogenic species isolated from mammals are more tightly rolled and shorter than saprophytic strains, while bacteria maintained under poor nutrient conditions have a more elongated structure and little motility (Cameron, 2015). The Leptospira virulence depends in large part on its LPS structure, which is the main recognized antigen during infection, and responsible for antigenic diversity and serogroup classification.
The serovar is the unit in which the Leptospira species are classified, and each exhibiting a different antigenic conformation. There are more than 300 serovars, which in turn have been classified by convenience in 32 serogroups, based on their antigenic homology (Caimi and Ruibal, 2020). Leptospira are conventionally divided into two species, the pathogenic Leptospira interrogans sensu lato and the saprophytic Leptospira biflexa sensu lato. Two strains will be considered as different serovars if, when performing a cross-agglutination absorption test (CAAT) with adequate amounts of a heterologous antigen, more than $10 \%$ of the homologous titer consistently remains in at least one of the two antisera. An unknown isolated strain may correspond to a known serovar from which a reference strain, already existing or not, is considered as a reference strain for that serovar (WHO, 2009). Although used for decades in Leptospira serological classification, CAAT is currently in disuse, due to technical limitation, and microagglutination test (MAT) has become the gold standard test (Caimi and Ruibal, 2020).

Also, increased availability of high throughout molecular methods, such as Next Generation Sequencing and DNA-DNA hybridization techniques, have provided tools for Leptospira biodiversity and genomic analysis, even in harsh soil and water environmental samples. Recent studies based in molecular taxonomy classification have discovered new clades and species. According to whole genome sequencing analyzes and molecular phylogenetics reconstruction by maximum likelihood of the 16s rRNA sequences, authors have identified 64 species in the genus Leptospira. Leptospira species are divided into three clades and one subclade. One of the clades includes pathogenic bacteria (P1) e.i, $L$. interrogans, L. kirschneri, L. noguchii, L. borgpetersenii, L. weilii, L. santarosai, L. alexanderi, L. alstonii, L.mayottensis, L. kmetyi. The other is an intermediate group (P2) e.i, L. wolffii, L. licerasiae, L. Inadai, L. fainei, L. broomii and the third includes nonpathogenic or saprophyte bacteria (S1) e.i, L. biflexa, L. idonii, L. meyeri, L. terpstrae, L. vanthielii, L. wolbachii, L. yanagawae, and others (Vincent et al., 2019; Guglielmini et al., 2019).

\section{Clinical presentation and diagnostics in humans}

The Leptospira incubation period lasts $\approx 10$ days and the disease occurs 5-14 days after the entry of the bacteria. The infection is divided into two phases, acute and immune, and may be asymptomatic in some cases (Wynwood et al., 2014). In $90 \%$ of patients, the leptospirosis acute phase lasts around 7 days. In this clinical stage, known as anicteric or benign, fever, photophobia, headache, arthralgia, chills, diaphoresis, asthenia, cough, nausea, vomiting and muscle pain can occur. In the immune phase, antibodies are produced (5-7 days after onset of infection), and excretion of the bacteria through urine starts when it establishes in the kidneys. However, in 5-10\% of cases there is an icteric or hepatonephrotic syndrome, also called Weil's syndrome, with severe multi-organ dysfunction (Galloway et al., 2019). Death from this infection is commonly due to renal failure and pulmonary hemorrhage (Brett-Major and Coldren, 2012). 
Since the clinical manifestation of leptospirosis depends on the contracted serovar (NOM-029-SSA2-1999), adequate diagnosis is a valuable support tool. Diagnostic tests can be divided into immunological, genomic and darkfield microscopy methods (Rajapakse et al., 2015). The immunological methods include the antibodies titration in serological samples by enzyme-linked immunosorbent assay (ELISA), and the gold standard method for leptospirosis diagnosis, microagglutination test (MAT). For MAT, titres $\geq 1: 100$ are considered positive, for individual or paired serum samples (WHO, 2009). In recent infections, titres $\geq 1: 400$ or fourfold increased between the acute and convalescent sample are classified as positive (Courdurie et al., 2017). The genomic methods for Leptospira detection, includes conventional $P C R$, real-time PCR, RT-PCR and isothermal amplification. These highly sensitive methods are based on the amplification of leptospiral constitutive genes, such as the 16S ribosomal RNA gene, the B subunit of DNA gyrase and secY, and genes specific to pathogenic species such as LipL32, Ifb1 and ompL1 (Ferreira et al., 2014; Waggoner and Pinsky, 2016).

\section{Ecological and environmental drivers for Leptospira transmission \\ Abiotic factors}

Leptospirosis occurrence varies greatly in the world. Certain climatic conditions, such as temperature (4-40 ${ }^{\circ} \mathrm{C}$ ), humidity greater than $20 \%$, and precipitation of each geographic location can favor the presence of Leptospira in some areas, being more frequent in tropical and subtropical climate, where the disease occurs throughout the year, while in temperate areas it occurs seasonally during the months with higher temperatures and rains. Leptospira also persists in nature, in soil and water at $\mathrm{pH}$ of 5.5-7.6, or even in cattle urine during 6-18 h at pH of 7-8 (Noguchi, 1918; Thibeaux et al., 2017). In addition, some serovars are capable of surviving up to 344 days in water and maintaining their virulence by regulating essential genes to promote survival even under extreme conditions of temperature and osmolarity, including the interaction with environmental bacteria and formation of biofilms, which allows them to survive in urine and increase its resistance to antibiotics (Vinod-Kumar et al., 2016; Barragan et al., 2017; Bierque et al., 2020). However, the complete information about the Leptospira extrinsic and intrinsic conditions for surviving in environment, are still under investigation.

\section{Biotic factors}

Animals that contract leptospirosis are divided into natural or maintenance, and incidental reservoirs. In natural reservoirs, the infection is endemic; leptospirosis is acquired at an early age and is usually transferred by direct contact with another infected animal. Incidental hosts are those that acquire the infection by direct contact with the natural reservoirs or by indirect contact with water or soil contaminated with Leptospira. Some species can be natural hosts for some serovars and incidental reservoirs for others (Levett, 2001). In addition, the same species can be a natural reservoir of different serovars in different regions of the planet (Hartskeerl and Terpstra, 1996; Putz and Nelly, 2020). The main natural reservoirs of pathogenic leptospires are wild and synanthropic species. The bacteria resides in the kidneys of these animals, and they commonly do not show clinical signs of the disease. The presence of Leptospira in wild animals including mammals (mainly rodentia), birds, reptiles, and amphibians, have been thoroughly reviewed by Vieira et al. (2018) and Cilia et al. (2021), where many unconventional hosts were identified in North and Latin-American countries. Although wildlife has a real role in the Leptospira transmission cycles, information is still scarce for many regions of the world (Vieira et al., 2018). In turn, the wildlife that naturally hosts Leptospira can infect humans and livestock animals with an important role in food systems, also, companion animals become an important source of infection for humans (Table 1).

Leptospirosis in incidental hosts causes a variety of acute clinical manifestations, like fever, respiratory disease, poor reproductive performance, low milk production, systemic failure, as well as urinary and hepatic insufficiency (Putz and Nally, 2020). However, in reservoirs, Leptospira can be present without causing major problems but could be eliminated through oral, renal, and reproductive ways (Ellis, 2015; Loureiro and Lilenbaum, 2020). Hence, carriers without symptoms may spread the infection possibly throughout their whole lives (Thiermann, 1982). Incidental leptospirosis in cattle is caused by serovars such as Pomona, Grippotyphosa and Icterohaemorrhagiae, related to pigs, rodents, and wildlife (Ellis, 2015). Natural leptospirosis is mainly caused by $L$. interrogans Hardjo, L. borgpetersenii Hardjo, L. santarosai Guaricura, all of the Sejroe serogroup (Loureiro and Lilenbaum, 2020). In swine, the most frequent serovars include $L$. Lora, Icterohaemorrhagiae, Pomona and Tarassovi (Petrakovsky et al., 2014). Due to its close contact with persons who work in the food production system, livestock animals play a critical role in the human-animal-environmental interface for Leptospira transmission because it represents a potential source for natural or incidental Leptospira to humans. Putz and Nally (2020), reported a comprehensive analysis of Leptospira serovar interactions and its clinical manifestation in some important species, as well as reviews of seroprevalence in animals from Latin-America and the Caribbean (Pinto et al., 2016; Pratt and Rajeev, 2018).

On the other hand, dogs are one of the most important hosts for Leptospira in urban and rural settings, and are part of the transmission cycle. Infection caused by the serovar Canicola is considered the most common, being the contact with urine of infected dogs the main intra and inter-species route of transmission. Canine leptospirosis due to Icterohaemorrhagiae serovar is less frequent, and is associated to the presence of rodents as these are the main carriers and transmitters. Due to the behavioral habits of dogs such as sniffing, licking, and courtship, when several animals get together, intraspecies and interspecies transmission is favored, being stray dogs an important source of infection for "domiciled" dogs (Luna et al., 2008). The domestic cat is another important companion animal that can be infected with Leptospira, however information is limited (Murillo et al., 2020).

Volumen XXIII, Número 3 
Table 1. Selected studies on Leptospira serovar identification in human, companion animals and livestock in different Latin-America countries.

Tabla 1. Estudios selectos sobre identificación de Leptospira en humanos, animales de compañía y animales de producción en diferentes países de Latinoamérica.

\begin{tabular}{|c|c|c|c|}
\hline Host & Serovars & Geographic localization & References \\
\hline \multirow{3}{*}{ Human } & $\begin{array}{l}\text { Andamana/Australis/Butembo/Copenhageni/Hardjo/Icterohaemorrhagiae/ } \\
\text { Patoc/Sentot/Tarassovi }\end{array}$ & Brazil & $\begin{array}{l}\text { Jorge et al., } 2017 \\
\text { Oliveira et al., } 2017\end{array}$ \\
\hline & $\begin{array}{l}\text { Ballum/Canicola/Hebdomadis/Icterohaemorrhagiae/Louisiana/Pomona/ } \\
\text { Pyrogenes }\end{array}$ & Cuba & Rodríguez et al., 2018 \\
\hline & $\begin{array}{l}\text { Bratislava/Canicola/Grippotyphosa/Hardjo//cterohaemorrhagiae/Pomona/ } \\
\text { Pyrogenes//Pomona/Portland/Tarassovi/Wolffi }\end{array}$ & Mexico & Galarde-López et al., 2021 \\
\hline \multirow{7}{*}{ Cattle } & $\begin{array}{l}\text { Australis/Bratislava/Canicola/Grippotyphosa/Hardjo/Icterohaemorrhagiae/ } \\
\text { Pomona/Pyrogenes/Sejroe/Shermani/Tarassovi/Wolffi }\end{array}$ & Brazil & $\begin{array}{l}\text { Campos et al., } 2017 \\
\text { Fávero et al., } 2018 \\
\text { Jorge et al., } 2017\end{array}$ \\
\hline & $\begin{array}{l}\text { Autumnalis/Ballum/Bratislava/Canicola/Djasiman/Icterohemorrhagiae/ } \\
\text { Mankarso/Tarassovi }\end{array}$ & Caribbean island Saint Kitts & Shiokawa et al., 2019 \\
\hline & $\begin{array}{l}\text { Bratislava/Canicola/Copenhageni/Grippotyphosa/Hardjo/Hebdomadis/ } \\
\text { Pomona/Tarassovi }\end{array}$ & Colombia & Taddei et al., 2021 \\
\hline & Hebdomadis/Pomona/Tarassovi & Costa Rica & Sequeira et al., 2016 \\
\hline & $\begin{array}{l}\text { Australis/Autumnalis/Bataviae/Canicola/Cophenhageni/Hardjo/ } \\
\text { Icterohaemorrhagiae/Pomona/Sejroe/Tarassovi }\end{array}$ & Ecuador & Ortega-Pacheco et al., 2020 \\
\hline & Ballum/Canicola/Forthbragg/Grippotyphosa/Hardjo/Icterhaemorragiae & Jamaica & Brown et al., 2011 \\
\hline & $\begin{array}{l}\text { Bratislava/Canicola/Grippotyphosa/H89 } \quad \text { hardjo } \\
\text { Icterhaemorragiae/Inifap/Paloalto/Pomona/Tarassovi/Wolffii }\end{array}$ & México & $\begin{array}{l}\text { Carmona-Gasca et al., } 2011 \\
\quad \text { Pedroza-Perez, } 2008 \\
\text { Zárate-Martínez et al., } 2015\end{array}$ \\
\hline \multirow{7}{*}{ Swine } & Castellonis/Icterohaemorrhagiae/Pomona/Wolffi & Argentina & Taddei et al., 2021 \\
\hline & $\begin{array}{l}\text { Australis/Autumnalis/Bratislava/Butembo/Canicola/Castellonis/Copenhageni/ } \\
\text { Grippotyphosa/Hardjo/Icterohaemorrhagiae/Panama/Patoc/Pomona/ } \\
\text { Pyrogenes/Shermani/Whitcombi }\end{array}$ & Brazil & $\begin{array}{l}\text { Miraglia et al., } 2008 \\
\text { Miraglia et al., } 2012 \\
\text { Moreira et al., } 2018 \\
\text { Valença et al., } 2013\end{array}$ \\
\hline & Bratislava/Copenhageni/Djasiman/Icterohaemorrhagiae/Mankarso & Caribbean island Saint Kitts & Shiokawa et al., 2019 \\
\hline & Canicola/Grippotyphosa/Hardjo/Icterohaemorrhagiae/Pomona & Colombia & Ospina-Pinto et al., 2019 \\
\hline & Bataviae/Canicola/Hardjo/Icterohaemorrhagiae & Ecuador & Ortega-Pacheco et al., 2020 \\
\hline & Bratislava/Forthbragg/Pomona & Jamaica & Brown et al., 2011 \\
\hline & $\begin{array}{l}\text { Ballum/Bataviae/Canicola/Djasiman/Hebdomadis/Lousiana/Panama/Pomona/ } \\
\text { Pyrogenes/Semaranga/Tarassovi }\end{array}$ & Mexico & Sequeira et al., 2016 \\
\hline \multirow{4}{*}{ Sheep } & $\begin{array}{l}\text { Australis/Autumnalis/Ballum/Bataviae/Bratislava/CopM20/Cynopteri/ } \\
\text { Djasiman/Grippotyphosa/Hardjo/Hebdomadis/Icterohaemorrhagiae/Javanica/ } \\
\text { Lousiana/Pomona/Pyrogenes/Wolffi }\end{array}$ & Brazil & $\begin{array}{l}\text { Almeida et al., } 2019 \\
\text { Campos et al., } 2017 \\
\text { Costa et al., } 2016\end{array}$ \\
\hline & Copenhageni/Djasiman/Hardjo/Icterohaemorrhagiae/Mankarso/Pomona & Caribbean island Saint Kitts & Shiokawa et al., 2019 \\
\hline & Canicola/Gripotyphosa/Hardjo/Icterohaemorrhagiae/Tarassovi & Ecuador & Orlando et al., 2020 \\
\hline & Kennewicki & Uruguay & Hamond et al., 2014 \\
\hline \multirow{3}{*}{ Goat } & Australis/Bratislava/Canicola/Icterohaemorrhagiae/Pomona/Pyrogenes/Wolffi & Brazil & Campos et al., 2017 \\
\hline & Bratislava/Djasiman/Hardjo/Mankarso & Caribbean island Saint Kitts & Shiokawa et al., 2019 \\
\hline & Hardjo-prajitno/Icterohemorrhagiae & Mexico & Gaytán-Camarillo et al., 2021 \\
\hline \multirow{4}{*}{ Dog } & Ballum/Butembo/Canicola/Copenhageni/Hond Utrecht IV/Kito & Brazil & $\begin{array}{l}\text { Jorge et al., } 2017 \\
\text { Miraglia et al., } 2012\end{array}$ \\
\hline & Canicola/Hardjo/Icterohaemorrhagiae/Grippotyphosa & Ecuador & Orlando et al., 2020 \\
\hline & $\begin{array}{l}\text { Ballum/Bratislava/Canicola17/Grippotyphosa/Icterohaemorrhagiae/ } \\
\text { Pyrogenes/Shermani }\end{array}$ & México & $\begin{array}{l}\text { Hernández-Ramírez et al., } \\
\qquad 2017\end{array}$ \\
\hline & Copenhageni & Trinidad & Suepaul et al., 2010 \\
\hline \multirow{3}{*}{ Cat } & Andamana/Autumnalis/Bataviae/Canicola/Patoc & Brazil & Dos Santos et al., 2017 \\
\hline & Autumnalis/Copenhageni & Chile & $\begin{array}{l}\text { Azócar-Aedo et al., } 2014 \\
\text { Dorsch et al., } 2020\end{array}$ \\
\hline & Australis/Canicola & Mexico & Ortega-Pacheco et al., 2020 \\
\hline \multirow{2}{*}{ Horse } & $\begin{array}{l}\text { Australis/Ballum/Bataviae/Bratislava/Canicola/Copenhageni/Grippotyphosa/ } \\
\text { Bratislava/Hardjo/Hardjo bovis/Wolffi/ }\end{array}$ & Brazil & $\begin{array}{l}\text { Dewes et al., } 2020 \\
\text { Jorge et al., } 2017\end{array}$ \\
\hline & $\begin{array}{l}\text { Canicola/Copenhageni/Sejroe/Cynopteri/Hardjo/Pomona/Autumnalis/ } \\
\text { Icterohaemorrhagiae/Grippotyphosa/Bataviae/Tarassovi/Australis }\end{array}$ & Ecuador & Orlando et al., 2020 \\
\hline
\end{tabular}




\section{Occupational and behavioral drivers for Leptospira trans-} mission

Occupational diseases are those acquired when exposed to risk factors related to work (WHO, 2002). Leptospirosis is considered an occupational disease for agricultural, livestock, meat, abattoir, and rice field workers, veterinarians, hunters, caretakers of wild animals, and farmers (Bengis et al., 2004; Bierque et al., 2020). This occurs due to close contact with animals which increases the risk of being exposed to potentially contaminated carcasses or live animals with Leptospira (WHO, 2009).

According to epidemiological estimates, $30 \%$ of leptospirosis cases are due to occupational exposure (Richard and Oppliger, 2015). Most of the infectious agents that cause zoonotic diseases are considered occupational risk factors, since they occur sporadically or chronically in different professions. Livestock worker's activities (such as milking) which include contact with animal urine, increase exposure and risk of leptospirosis. In addition, making homemade cheese and washing hands or drinking water from cattle drinking fountains could be risk factors. In addition, the risk of contracting the infection is greater in personnel that assist in the livestock delivery and manipulate waste products, and it is aggravated when not wearing personal protective equipment (PPE) (WHO, 2009). There is also a greater risk in cattle owners or in people, whose occupation involves the manipulation of pig or bovine tissues (Leal-Castellanos et al., 2003). Carrying out necropsies on mortality events and obstetric management of sows is a routine activity on technified farms, and due the asymptomatic presentation of the disease, it represents a high risk for workers (Botazzo et al., 2002). In addition, workers previously diagnosed with leptospirosis are more likely to be seropositive than those who have not previously had the disease. This suggests that those who already suffered from the disease may present behaviors that increase their exposure (Sanhueza et al., 2017).

Moreover, people who do outdoor activities are more at risk of contracting leptospirosis than those who work indoors (Kamath et al., 2014). In a meta-analysis study carried out in 7,000 feverish cases globally associated with travelers, a prevalence of $0.21-2.65 \%$ for Leptospira was found (Bandara et al., 2014). Other behaviors that increase the risk of getting sick are swimming in areas where cattle drink water, and keeping puddles near the house. Likewise, people with skin cuts exposed to floodwater are at greater risk of having leptospirosis (Leal-Castellanos et al., 2003).

In addition, other studies revealed that having frequent contact with animals such as rats, mice, guinea pigs and poultry, or living with pets such as dogs, cats, and rats, and walking barefoot, increases the risk of leptospirosis (Brockmann et al., 2016; Sanhueza et al., 2017). Other risk factors associated with leptospirosis in humans, are the limited knowledge of the disease and its transmission, low educational attainment, younger age, and unhealthy behaviors (inadequate or missing hand washing and PPE) (Brown et al., 2011). Also, belonging to the male gender, working age, working in the field, and poverty, are risk factors associated with the disease (Carvajal and Fagerstrom, 2017; Dhewantara et al., 2018).

\section{Transmission of Leptospira at human-animal-environ- ment interfaces}

After a Leptospira infection, natural reservoirs, such as herbivores and other animals, may become asymptomatic carriers and, in consequence, an important source of Leptospira shedding into the environment by bacteria secretion in urine. This is a renal carrier state and considered the most important mechanism that enables the persistence of leptospirosis in the environment (Adler and de la Peña-Moctezuma, 2010). Therefore, during its life cycle it can be transmitted to incidental hosts, such as humans or domestic livestock, Figure 1 (Bengis et al., 2004; Ko et al., 2009; Haake and Levett, 2015). Once the leptospires enter a new host, they spread through the peritubular capillaries or glomeruli to the kidneys, via the hematogenous route. When they enter the renal tubular lumen, they invade the brush border of the proximal tubule through which urine is eliminated (Haake and Levett, 2015).

After direct exposure to infected urine, milk or reproductive fluids of carrier animals, or indirect exposure to soil, water or food contaminated with the bacteria (Galloway et al., 2019), Leptospira can enter a new host through skin lesions and oral, genital, nose, or conjunctive mucous mem-

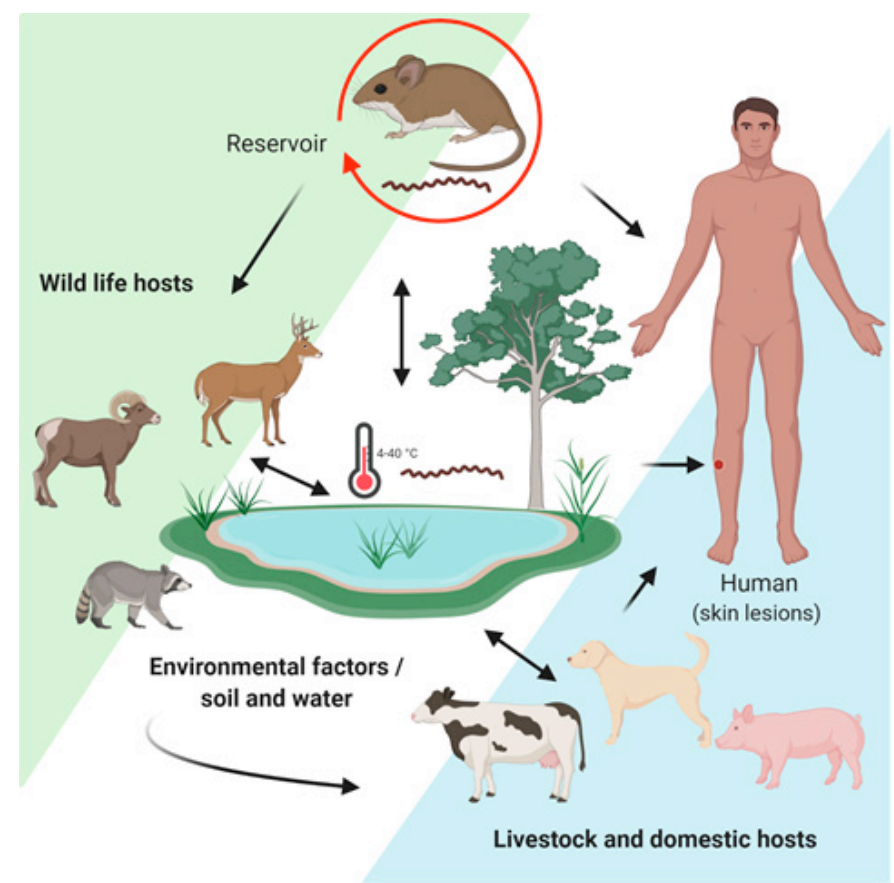

Figure 1. The cycle of Leptospira transmission influenced by environmental factors. Occurrence is affected by the transmission dynamics between asymptomatic and synantropic (rodents) wild reservoirs carriers, and other wildlife, environmental, and domestic and livestock that acts as incidental or reservoir hosts. Transmission to human is mediated by contact with hosts or direct by contaminated water and soil. Pathogenic Leptospira penetrates through mucous membranes and skin lesions (Levet, 2015) (Created by BioRender.com).

Figura 1. El ciclo de transmisión de Leptospira influenciado por factores ambientales. 
branes. Although indirect contact is the most common form of Leptospira transmission, direct contact is also associated with occupational transmission (Haake and Levett, 2015).

Humans can excrete leptospires in urine for several weeks, and even years after the acute phase of the disease (Bharti et al., 2003). However, there is no evidence supporting this as an important source of Leptospira in the environment, since their urine is acidic and leptospires require a $\mathrm{pH}$ of 6-8 to survive, therefore, human-to-human transmission is rare (Castillo-Hernández, 2014; Kamath et al., 2014). Leptospira can also spread through sexual intercourse (Harrison and Fitzgerald, 1988). In addition, mothers can infect the fetus through the placenta, which can cause fetal death or miscarriage, the latter being more common in women who have developed leptospirosis in the first months of pregnancy (Haake and Levett, 2015). Although the mother's disease not necessarily affects the fetus (Shaked et al., 1993), the baby could acquire the infection during breastfeeding (Bolin Koellner, 1988). In addition, blood can also participate as an infectious medium since the bacteria are present in it the first 10 days of infection (Budihal and Perwez, 2014).

\section{Epidemiology of human leptospirosis}

Annually there are approximately 1.03 million cases of leptospirosis and 58,900 deaths worldwide, and is one of the zoonoses that causes more morbidity and mortality globally (Costa et al., 2015). The incidence is seasonal, and can be associated with climatic conditions; in temperate regions the incidence rate is $0.1-1 / 100,000$ inhabitants, in humid tropical climates the incidence rate is $10 / 100,000$ inhabitants, and in regions with outbreaks or with risk groups is $100 /$ 100,000 inhabitants (WHO, 2009). There is a greater number of cases in rainy seasons in warm and dry regions, since water provides the means of survival for Leptospira (Levett, 2004). In addition, it is endemic to tropical and subtropical zones, such as Latin-America and the Caribbean (Adler and de la Peña-Moctezuma, 2010). South America is the most affected region, despite many cases are reported in other northern countries (Schneider et al., 2017; Pereira et al., 2018).

In a meta-analysis assessment of 17 studies carried out in different Latin-American countries (including Colombia and Puerto Rico), a prevalence of $16 \%$ was found in 13,539 cases with acute fever (Moreira et al., 2018). In another metaanalysis study using data provided by health authorities from different Latin-American and Caribbean countries, based on data published in the 2006-2013 period, the countries with the highest prevalence reports were Trinidad and Tobago with 22 / 100,000 inhabitants, and Uruguay with 13.9 / 100,000 inhabitants. The countries that reported the highest proportion of positive cases for Leptospira were Guyana with $37 \%$, Jamaica with $31.9 \%$, Cuba with $27.6 \%$, Peru with 27.3 $\%$ and Argentina with $22.4 \%$ (Pulido-Villamarín et al., 2014).

In a study conducted by Meny et al. (2019), in a region of Uruguay, a Leptospira seroprevalence of $46 \%$ was found; in addition, the contact with animals and unsafe water conditions were observed as the main risk factors (Meny et al.,
2019). On the other hand, in a retrospective study carried out by the Costa Rican Ministry of Health in the period 2011-2015, a prevalence of $10.6 \%$ was found in 5,056 patient samples (Carvajal and Fagerstrom, 2017). A descriptive epidemiological study carried out in Brazil, described the confirmed cases for the 2007-2016 period, reporting 39,263 cases with an annual mean of 3,926 and an incidence of 1.02 $/ 100,000$ inhabitants. They also estimated a lethality of $8.9 \%$ with a distribution of $79.2 \%$ in urban areas with little sanitary infrastructure, which predisposed the infestation by rodents and contact with water and/or flood mud (Flores et al., 2020). In Latin-America through national surveillance programs during 2010-2014, cases mainly distributed in Brazil, Peru, Colombia, and Ecuador (Schneider et al., 2017).

In México, during a dengue outbreak in the Yucatan Peninsula, it was found that $14 \%$ of suspected dengue cases patients had leptospirosis. The symptoms and signs that manifested the positive people to Leptospira belonged to the anicteric presentation, and were like those of dengue. The serovars found were Canicola, Pomona and Grippotyphosa (Zavala-Velázquez et al., 1998). Since leptospirosis clinical presentation is confused with other febrile diseases, is considered a public health problem that is not addressed and is underdiagnosed (Velasco-Castrejón et al., 2009). In Tamaulipas, $8.2 \%$ of the trail workers had seropositivity to leptospirosis and the predominant serovars were Bratislava and Hardjo; two people had antibodies for three serovars, eight for two and fourteen for only one (Rodríguez-Parra et al., 2009).

In Mexico, during 1992-1997, the National Institute of Epidemiological Diagnosis and Reference found a seropositivity of $30.3 \%$ for leptospirosis. The most common serovars were Pomona, Canicola and Icterohaemorrhagiae. Later, in 1998, they registered 119 leptospirosis cases and the majority was concentrated in Distrito Federal, Hidalgo and Guerrero (NOM-029-SSA2-1999). During 2000-2010, there were 1,547 cases and 198 deaths by leptospirosis in Mexico (Sanchez-Montes et al., 2015). Therefore, the case-fatality rate was $12.8 \%$, higher than Malaysia (1.47 \%) (Tan et al., 2016), Trinidad and Tobago (5.8 \%) (Mohan et al., 2009) and Hawaii, United States (0.5\%) (Katz et al., 2011). This could be due to the delay in the diagnosis, the confusion of the symptoms with those of other diseases or an adequate treatment (Budihal and Perwez, 2014). The only states that did not present cases were Durango, Baja California, Queretaro, Guanajuato, and Zacatecas. While those with the highest incidence were Veracruz, Tabasco, and Sinaloa, the actual number of people who had leptospirosis is unknown (Sanchez-Montes et al., 2015). It was determined that leptospirosis cases in Mexico occur throughout the year, however endemic peaks were observed during the months of August, September, and October (Yescas-Benitez et al., 2020).

In several studies conducted in different regions of Mexico, in occupational exposed workers and rural communities, authors found a 12-40\% seroprevalence (Leal-CasteIlanos et al., 2003; Rivera-Benitez et al., 2014; Vado-Solís et al., 
2014; Alvarado-Esquivel et al., 2015; Cordova-Robles, 2019). The main serovars were Canicola and Hardjo, indicating that dogs and cattle are an important source of contagion for livestock workers. Although Mexico has a surveillance and control program for leptospirosis outbreaks, many cases might not be detected due to lack of differential diagnosis with other febrile illnesses or mild/asymptomatic cases.

\section{Prevention and control measures Vaccines and prophylaxis}

The application of vaccines in humans and animals, is an option to prevent leptospirosis, and some vaccines may protect against serovars different from the one used to manufacture them due to cross-reactivity (Matsuo et al., 2000). However, they can be serotype dependent and unable to induce an immune response against other serovars (Sonrier et al., 2000). In addition, the genetic and phenotypic diversity of infectious leptospires is an obstacle to the development of vaccines (Grassmann et al., 2017). Only one country in Latin-America, Cuba, uses routinely human vaccination against Leptospira (Pereira et al., 2018), Normally using inactivated vaccines applied to domestic animals and livestock. In some countries, it is also applied to human populations at risk. However, due to side effects in humans, lack of cross protection and short duration of immunity, they are not used globally (Grassmann et al., 2017).

Several vaccines are available; bacterins are vaccines made from whole dead cells and are the most common type of biologic available globally. The disadvantages are high production costs, local and systemic reactions, and a short period of immunity. In addition, protection is restricted to antigenically related serovars. Therefore, polyvalent vaccines have been used in domestic animals such as cattle. The immune protection can last from 6 months to 3 years depending on the adjuvants used in the vaccine, and human vaccine formulations have shown efficacy rates of $60-100 \%$ (Koizumi and Watanabe, 2005).

Recombinant DNA vaccines have advantages such as low production cost, stability, and ability to elicit humoral and cell-mediated immune response against several serovars in the long term. DNA vaccines have been designed against conserved genes among the pathogenic leptospires and are highly immunogenic. The insertion of genes such as LipL32, OmpL1 and LipL41 in different vectors have been tested as vaccines in animal models (Bashiru and Bahaman, 2018).

Another alternative available against leptospirosis is chemoprevention prophylaxis, mainly used when the infection risk is high and there will be a forced exposure. Oral ingestion of a weekly $200 \mathrm{mg}$ dose of doxycycline has been effective in reducing clinical infection, but it does not prevent infection, although significantly reduces morbidity and mortality (Sehgal et al., 2000).

\section{Hygiene, PPE and environmental control}

Among the leptospirosis prevention measures, is the use of protecting clothing that covers wounds and reduces the risk of disease appearance (OMS, 2008), as well as personal protection equipment such as overalls, gloves, boots, and goggles, when in contact with livestock, preventing skin and mucous membranes exposure (NOM-029-SSA2-1999). To prevent leptospirosis, hands should be washed after contact with animals and their derivatives, and rodent population, should be controlled. In addition, it is necessary to disinfect animal breeding sites. Furthermore, people should have regular clinical and laboratory tests, especially if there is a suspicion of infection. Vaccination of cattle and pets is also necessary. It is important to avoid swimming in waters that animals have access to, adding chlorine to water sources for human use, and boiling it before consumption. Likewise, avoiding the formation of water clusters in work areas is important to reduce the potential for leptospirosis outbreaks (NOM-029-SSA2-1999).

\section{Education and interventions}

The risk of infection is reduced by avoiding contact with the carrier host or contaminated environment. It is important to raise awareness among the population, especially at-risk groups, about leptospirosis, so an early detection and adequate treatment is possible (WHO, 2009). This is achievable through education campaigns or interventions promoting preventive health behaviors among high-risk groups (Rahman et al., 2018).

\section{Surveillance and future challenges}

Surveillance systems and health policies for human leptospirosis in Latin-America have been reviewed previously by Schneider et al. (2017) and Pereira et al. (2018). The identification of Leptospira reservoirs, and the understanding of the eco-epidemiology of the bacteria in the environment and in animal hosts, are key in designing strategies for control. Different serovars of Leptospira may differ in their virulence, so the true magnitude of the health risk due to leptospirosis is unknown. On the other hand, it is possible for the infection to remain asymptomatic and undiagnosed, resulting in an underestimation of the seroprevalence. Therefore, it is necessary to investigate which serovars are in the affected area to implement or improve vaccination strategies, and determine the actual number of people that are seropositive (Richard and Oppliger, 2015; Sanchez-Montes et al., 2015). Once taught as a predominant disease in tropical countries, some researchers estimate that climate change will increase distribution range due to changes in temperature, extreme rainy season and flooding events that will increase occurrence of Leptospira and leptospirosis in the next years (Lau et al., 2010), thus many gaps in knowledge need to be addressed.

\section{CONCLUSIONS}

Leptospirosis is a re-emerging zoonotic disease of global importance. Human and animal leptospirosis cases are increasingly detected in many regions and territories in rural and urban settings in Latin-America, mainly in SouthAmerican countries. Serovar, host diversity and socio- 
environmental conditions mediate complex interactions of its ecology and epidemiology in this region. Diagnosis of leptospirosis is not conducted systematically in all regions of Latin-America, including Mexico, although surveillance of the disease in human and animal with appropriate diagnostic methods might play an important role in prevention and control of leptospirosis outbreaks. Also, risk mitigation measures in occupational exposed populations through modifications in behavioral determinants, animal vaccination and educational interventions might help decrease transmission to human hosts. Although leptospirosis is an important zoonotic disease at human-animal-environmental interfaces, it is neglected and underdiagnosed. Studies with a One Health approach in Latin-American regions are relevant and necessary, representing a challenge for public and animal health, and food systems.

\section{ACKNOWLEDGMENTS}

We acknowledge Dr. Salvador Icedo Núñez content review and comments. We thank to Ing. Rodrigo Sánchez for the english edition of the manuscript

\section{REFERENCES}

Almeida, D.S., Paz, L.N., de Oliveira, D.S., Silva, D.N., Ristow, P., Hamond, C., Costa, F., Portela, R.W., Estrela-Lima, A. and Pinna, M.H. 2019. Investigation of chronic infection by Leptospira spp. in asymptomatic sheep slaughtered in slaughterhouse. PloSone. 14:e0217391.

Adler, B. and de la Peña-Moctezuma, A. 2010. Leptospira and leptospirosis. Veterinary Microbiology. 140:287-296.

Alvarado-Esquivel, C., Sanchez-Anguiano, L.F. and HernandezTinoco, J. 2015. Seroepidemiology of Leptospira Exposure in General Population in Rural Durango, Mexico. BioMed Research International. 2015:460578.

Azócar-Aedo, L., Smits, H. and Monti, G. 2014. Leptospirosis in dogs and cats: epidemiology, clinical disease, zoonotic implications and prevention. Archivos de Medicina Veterinaria. 46:337-348.

Bandara, M., Ananda, M., Wickramage, K., Berger, E. and Agampodi, S. 2014. Globalization of leptospirosis through travel and migration. Globalization and Health. 10:1-9.

Barragan, V., Olivas, S., Keim, P. and Pearson, T. 2017. Critical knowledge gaps in our understanding of environmental cycling and transmission of Leptospira spp. Applied and Environmental Microbiology. 83.

Bashiru, G. and Bahaman, A.R. 2018. Advances \& challenges in leptospiral vaccine development. The Indian Journal of Medical Research. 147:15-22.

Bengis, R.G., Leighton, F.A., Fischer, J.R., Artois, M., Morner, T. and Tate, C.M. 2004. The role of wildlife in emerging and reemerging zoonoses. Revue Scientifique et Technique-Office International des Épizooties. 23:497-511.

Bharti, A.R., Nally, J.E., Ricaldi, J.N., Matthias, M.A., Diaz, M.M., Lovett, M.A., Levett, P.N., Gilman, R.H., Willig, M.R., Gotuzzo, E., Vinetz, J.M. and Peru-United States Leptospirosis, C. 2003. Leptospirosis: a zoonotic disease of global importance. The Lancet. Infectious diseases. 3:757-771.
Bierque, E., Thibeaux, R., Girault, D., Soupé-Gilbert, M.E. and Goarant, C. 2020. A systematic review of Leptospira in water and soil environments. PLoSone. 15:e0227055.

Bolin, C.A. and Koellner, P. 1988. Human-to-human transmission of Leptospira interrogans by milk. The Journal of Infectious Diseases. 158:246-247.

Botazzo, A., Freitas, J.C., Bracarense, A.P., Eckehardt, E. and Oliveira, R. 2002. Leptospirosis in slaughtered sows: serological and histopathological investigation. Brazilian Journal of Microbiology. 33:174-177.

Brett-Major, D.M. and Coldren, R. 2012. Antibiotics for leptospirosis. The Cochrane database of systematic reviews. CD008264.

Brockmann, S.O., Ulrich, L., Piechotowski, I., Wagner-Wiening, C., Nockler, K., Mayer-Scholl, A. and Eichner, M. 2016. Risk factors for human Leptospira seropositivity in South Germany. SpringerPlus. 5:1796.

Brown, P., McKenzie, M., Pinnock, M. yand McGrowder, D. 2011. Environmental risk factors associated with leptospirosis among butchers and their associates in Jamaica. The international Journal of Occupational and Environmental Medicine. 2:47-57.

Budihal, S.V. and Perwez, K. 2014. Leptospirosis diagnosis: competancy of various laboratory tests. Journal of Clinical and Diagnostic Research: JCDR. 8:199-202.

Caimi, K. and Ruybal, P. 2020. Leptospira spp., a genus in the stage of diversity and genomic data expansion. Infection, Genetics and Evolution. 81:104241.

Cameron, C.E. 2015. Leptospiral structure, physiology, and metabolism. Current Topics in Microbiology and Immunology. 387:21-41.

Campos, Â.P., Miranda, D.F.H., Rodrigues, H.W.S., Lustosa, M.d.S.C., Martins, G.H.C., Mineiro, A.L.B.B., Castro, V., Azevedo, S.S. and de Sousa Silva, S.M.M. 2017. Seroprevalence and risk factors for leptospirosis in cattle, sheep, and goats at consorted rearing from the State of Piauí, northeastern Brazil. Tropical animal health and production. 49:899-907.

Carmona-Gasca, C.A., Lara, L.L., Castillo-Sánchez, L.O., RamírezOrtega, J.M., Palomera, C.L. and de la Peña-Moctezuma, A. 2011. Detection of Leptospira santarosai and L. kirschneri in cattle: new isolates with potential impact in bovine production and public health. Veterinaria Mexico. 42:277288.

Carvajal, M.P. and Fagerstrom, K.A. 2017. Epidemiology of Leptospirosis in Costa Rica 2011-2015. Current Tropical Medicine Reports. 4:41-46.

Castillo-Hernández, M. 2014. Leptospira en ganado bovino. Tesis de licenciatura. Universidad Agraria Antonio Narro, Saltillo, Coahuila.

Cilia, G., Bertelloni, F., Albini, S. and Fratini, F. 2021. Insight into the Epidemiology of Leptospirosis: A Review of Leptospira Isolations From “Unconventional" Hosts. Animals. 11:191.

Cordova-Robles, N.F. 2019. Leptospirosis and su transmisión zoonótica en trabajadores de explotaciones de ganado bovino. Tesis de maestría. Centro de Investigación en Alimentación y Desarrollo, A.C., Hermosillo, Sonora.

Costa, D.F.D., Silva, A.F.d., Brasil, A.W.d.L., Loureiro, A.P.P., Santos, F.A.d., Azevedo, S.S.d., Lilenbaum, W. and Alves, C.J. 2016. Leptospirosis in native mixed-breed sheep slaughtered in a semiarid region of Brazil. Ciência Rural. 47. 
Costa, F., Hagan, J.E., Calcagno, J., Kane, M., Torgerson, P., Martinez-Silveira, M.S., Stein, C., Abela-Ridder, B. and Ko, A.I. 2015. Global Morbidity and Mortality of Leptospirosis: A Systematic Review. PLoS Neglected Tropical Diseases. 9:e0003898.

Courdurie, C., Le Govic, Y., Bourhy, P., Alexer, D., Pailla, K., Theodose, R., Cesaire, R., Rosine, J., Hochedez, P. and Olive, C. 2017. Evaluation of different serological assays for early diagnosis of leptospirosis in Martinique (French West Indies). PLoS Neglected Tropical Diseases. 11:e0005678.

Cruz-Romero, A., Alvarado-Esquivel, C., Romero-Salas, D., Alvarado-Félix, Á.O., Sánchez-Montes, S., Hernández-Tinoco, J. and Sánchez-Anguiano, L.F. 2018. Seroepidemiology of Leptospira infection in backyard pigs in Durango State, Mexico. European Journal of Microbiology and Immunology. 8:87-90.

Dewes, C., Fortes, T.P., Machado, G.B., Pacheco, P.S., Silva, J.P.M., Neto, A.C.P.S., Félix, S.R. and da Silva, É.F. 2020. Prevalence and risk factors associated with equine leptospirosis in an endemic urban area in Southern Brazil. Brazilian Journal of Development. 6:58380-58390.

Dhewantara, P.W., Mamun, A.A., Zhang, W.Y., Yin, W.W., Ding, F., Guo, D., Hu, W., Costa, F., Ko, A.l. and Soares Magalhaes, R.J. 2018. Epidemiological shift and geographical heterogeneity in the burden of leptospirosis in China. Infectious-Diseases of Poverty. 7:57.

Dorsch, R., Ojeda, J., Salgado, M., Monti, G., Collado, B., Tomckowiack, C., Tejeda, C., Müller, A., Eberhard, T. and Klaasen, H.L. 2020. Cats shedding pathogenic Leptospira spp.-An underestimated zoonotic risk? PloS one. 15:e0239991.

Dos Santos, L.F., Guimarães, M.F., de Souza, G.O., da Silva, I.W.G., Santos, J.R., Azevedo, S.S., Labruna, M.B., Heinemann, M.B. and Horta, M.C. 2017. Seroepidemiological survey on Leptospira spp. infection in wild and domestic mammals in two distinct areas of the semi-arid region of northeastern Brazil. Tropical animal health and production. 49:1715-1722.

Ellis, W.A. 2015. Animal leptospirosis. Current Topics in Microbiology and Immunology. 387:99-137.

Fávero, J.F., Fritzen, A., Lovato, L.T., Martins, P., Baldissera, M.D., Stefani, L.M. and Da Silva, A.S. 2018. Immune response of a commercial vaccine against Leptospira interrogans: antibodies and cytokine levels. Microbial pathogenesis. 114:46-49.

Ferreira, A.S., Costa, P., Rocha, T., Amaro, A., Vieira, M.L., Ahmed, A., Thompson, G., Hartskeerl, R.A. e Inácio, J. 2014. Direct detection and differentiation of pathogenic Leptospira species using a multi-gene targeted real time PCR approach. PLoS One. 9:e112312.

Flores, D.M., Flores, L.M., Romanielo, A.F.R., Dutra, G.S., Souza, A.V., Finta, A.L.N., de Lima, D.K.F. and de Sousa Machado, L.C. 2020. Epidemiologia da Leptospirose no Brasil 2007 a 2016. Brazilian Journal of Health Review. 3:2675-2680.

Galarde-López, M., Bobadilla-del Valle, M., SánchezZamoranoL.M., Ordaz-Vázquez, A., Velazquez-Meza, M.E., Soberanis-Ramos, O. 2021. High exposure to pathogenic leptospires by the population residing in dairy farms in Hidalgo, Mexico. Brazilian Journal of Microbiology. 52:10131019.
Galloway, R.L., Schafer, I.J. and Stoddard, R.A. 2019. TravelRelated Infectious Diseases: Leptospirosis. En: CDC yellow book 2020:Health information for international travel. Brunette, G.W. and Nemhauser, J.B. (Eds.), Oxford University Press, New York.

Garba, B., Bahaman, A.R., Bejo, S.K., Zakaria, Z., Mutalib, A.R. and Bande, F. 2018. Major epidemiological factors associated with leptospirosis in Malaysia. Acta Tropica. 178:242-247.

Gaytán-Camarillo, F., Rico-Chávez, O., Palomares-Resendiz, E.G., Gutiérrez-Hernández, J.L., Díaz-Aparicio, E. and HerreraLópez, E. 2021. Spatial autocorrelation and co-occurrence of six serovarieties of Leptospira in goat herds of the State of Guanajuato, Mexico. Brazilian Journal of Microbiology. 1-8.

González, H. and Macías, A. 2017. Agrifood Vulnerability and Neoliberal Economic Policies in Mexico. Review of Agrarian Studies. 7:72-106.

Grassmann, A., Souza, J. and McBride, A. 2017. A Universal Vaccine against Leptospirosis: Are We Going in the Right Direction? Frontiers in Immunology. 8:256.

Guglielmini, J., Bourhy, P., Schiettekatte, O., Zinini, F., Brisse, S., Picardeau, M. 2019. Genus-wide Leptospira core genome multilocus sequence typing for strain taxonomy and global surveillance. PLoS Negl Trop Dis 13(4):e0007374. https://doi. org/10.1371/journal.pntd.0007374.

Haake, D.A. and Levett, P.N. 2015. Leptospirosis in humans. Current Topics in Microbiology and Immunology. 387:65-97.

Hamond, C., Pinna, A., Martins, G. and Lilenbaum, W. 2014. The role of leptospirosis in reproductive disorders in horses. Tropical Animal Health and Production. 46:1-10.

Harrison, N. and Fitzgerald, W. 1988. Leptospirosis--can it be a sexually transmitted disease? Postgraduate Medical Journal. 64:163.

Hartskeerl, P. and Terpstra, W. 1996. Leptospirosis in wild animals. Veterinary Quarterly. 18:149-150.

Hartskeerl, R.A. and Smythe, L.D. 2015. The role of leptospirosis reference laboratories. Current Topics in Microbiology and Immunology. 387:273-288.

Hernández-Ramírez, C., Gaxiola-Camacho, S., Osuna-Ramírez, I., Enríquez-Verdugo, I., Castro, N. and López-Moreno, H. 2017. Prevalence and risk factors associated with serovars of Leptospira in dogs from Culiacan, Sinaloa. Veterinaria México. 4:1-12.

Jones, K.E., Patel, N.G., Levy, M.A., Storeygard, A., Balk, D., Gittleman, J.L. and Daszak, P. 2008. Global trends in emerging infectious diseases. Nature. 451:990-993.

Jorge, S., Schuch, R.A., de Oliveira, N.R., da Cunha, C.E.P., Gomes, C.K., Oliveira, T.L., Rizzi, C., Qadan, A.F., Pacce, V.D. and Recuero, A.L.C. 2017. Human and animal leptospirosis in Southern Brazil: A five-year retrospective study. Travel medicine and infectious disease. 18:46-52.

Kamath, R., Swain, S., Pattanshetty, S. and Nair, N.S. 2014. Studying risk factors associated with human leptospirosis. Journal of Global Infectious Diseases. 6:3-9.

Katz, A.R., Buchholz, A.E., Hinson, K., Park, S.Y. and Effler, P.V. 2011. Leptospirosis in Hawaii, USA, 1999-2008. Emerging Infectious Diseases. 17:221.

Ko, A.I., Goarant, C. and Picardeau, M. 2009. Leptospira: the dawn of the molecular genetics era for an emerging zoonotic pathogen. Nature Reviews Microbiology. 7:736-747. 
Koizumi, N. and Watanabe, H. 2005. Leptospirosis vaccines: past, present, and future. Journal of Postgraduate Medicine. 51:210-214.

Lau, C.L., Smythe, L.D., Craig, S.B. and Weinstein, P. 2010. Climate change, flooding, urbanisation and leptospirosis: fuelling the fire? Transactions of the Royal Society of Tropical Medicine and Hygiene. 104:631-638.

Leal-Castellanos, C.B., Garcia-Suarez, R., Gonzalez-Figueroa, E., Fuentes-Allen, J.L. and Escobedo-de la Penal, J. 2003. Risk factors and the prevalence of leptospirosis infection in a rural community of Chiapas, Mexico. Epidemiology and Infection. 131:1149-1156.

Levett, P.N. 2001. Leptospirosis. Clinical Microbiology Reviews. 14:293-326.

Levett, P.N. 2004. Leptospirosis: a forgotten zoonosis? Clinical and Applied Immunology Reviews. 4:435-448.

Levett, P.N. 2015. Systematics of leptospiraceae. Current Topics in Microbiology and Immunology. 387:11-20.

Levett, P.N. and Haake, D.A. 2014. Leptospira species (leptospirosis). En: Mandell, Douglas, and Bennett's Principles and Practice of Infectious Diseases. Bennett, J.E., Dolin, R. and Blaser, M.J. (Eds.), 2714-2720.e2712. Elsevier Health Sciences.

Loureiro, A.P. and Lilenbaum, W. 2020. Genital bovine leptospirosis: A new look for an old disease. Theriogenology. 141:41-47.

Luna, A., Moles, C., Gavaldón, R., Nava, V. and Salazar, G. 2008. La leptospirosis canina y su problemática en México. Revista de Salud Animal. 30:01-11.

Matsuo, K., Isogai, E. and Araki,Y.2000.Control of immunologically crossreactive leptospiral infection by administration of lipopolysaccharides from a nonpathogenic strain of Leptospira biflexa. Microbiology and Immunology. 44:887890.

Meny, P., Menéndez, C., Ashfield, N., Quintero, J., Rios, C., Iglesias, T., Schelotto, F. and Varela, G. 2019. Seroprevalence of leptospirosis in human groups at risk due to environmental, labor or social conditions. Revista Argentina de Microbiología. 51:324-333.

Miraglia, F., de Morais, Z.M., Dellagostin, O.A., Seixas, F.K., Freitas, J.C., Zacarias, F.G., Delbem, Á.C., Ferreira, T.S., Souza, G.O. and Hartskeerl, R.A. 2012. Molecular and serological characterization of Leptospira interrogans serovar Canicola isolated from dogs, swine, and bovine in Brazil. Tropical Animal Health and Production. 45:117-121.

Miraglia, F., Moreno, A.M., Gomes, C.R., Paixão, R., Liuson, E., Morais, Z.M., Maiorka, P., Seixas, F.K., Dellagostin, O.A. and Vasconcellos, S.A. 2008. Isolation and characterization of Leptospira interrogans from pigs slaughtered in São Paulo State, Brazil. Brazilian Journal of Microbiology. 39:501-507.

Mohan, A.R., Cumberbatch, A., Adesiyun, A.A. and Chadee, D.D. 2009. Epidemiology of human leptospirosis in Trinidad and Tobago, 1996-2007: a retrospective study. Acta-Tropica. 112:260-265.

Moreira, J., Bressan, C.S., Brasil, P. and Siqueira, A.M. 2018. Epidemiology of acute febrile illness in Latin-America. Clinical Microbiology and Infection. 24:827-835.

Murillo, A., Goris, M., Ahmed, A., Cuenca, R. and Pastor, J. 2020. Leptospirosis in cats: Current literature review to guide diagnosis and management. Journal of Feline Medicine and Surgery. 22:216-228.
Noguchi, H. 1918. The Survival of Leptospira (Spirochaeta) Icterohaemorrhagiae in Nature; Observations Concerning Microchemical Reactions and Intermediary Hosts. The Journal of Experimental Medicine. 27:609-625.

Norma oficial mexicana NOM-029-SSA2-1999, para la vigilancia epidemiológica, prevención y control de la leptospirosis en el humano. [Consultado 20 Febrero 2021] 1999. Disponible en: http://www.salud.gob.mx/unidades/cdi/nom/029ssa29. html.

Oliveira, M.A.A., Leal, É.A., Correia, M.A., Serufo Filho, J.C., Dias, R.S. and Serufo, J.C. 2017. Human leptospirosis: occurrence of serovars of Leptospira spp. in the state of Minas Gerais, Brazil, from 2008 to 2012. Brazilian Journal of Microbiology. 48:483-488.

OMS. 2008. Guía para el diagnóstico, vigilancia y control. Serie de manuales técnicos 12 . Rio de Janeiro. Organización Panamericana de la Salud/Organización Mundial de la Salud.

Orlando, S.A., Perez, A., Sanchez, E., de la Cruz, C., Rugel, O. and Garcia-Bereguiain, M.A. 2020. High seroprevalence of antiLeptospira spp. antibodies in domestic and wild mammals from a mixed use rescue center in Ecuador: Lessons for "One Health" based conservation strategies. One Health. 10:100140.

Ortega-Pacheco, A., Gutiérrez-Blanco, E., Cauich-Mendez, W. and Jimenez-Coello, M. 2020. Leptospira spp. in cats from tropical Mexico. Journal of Zoonotic Diseases. 4:1-8.

Ospina-Pinto, M.C., Rincón-Pardo, M., Soler-Tovar, D. and Hernández-Rodríguez, P. 2019. Alteration of the Reproductive Indicators by the Presence of Leptospira spp. in Sows of Swine Farms. Acta Scientiae Veterinariae. 47.

Pedroza-Perez, D. 2008. Prevalencia de leptospirosis en ganado bovino productor de carne en el estado de Sonora. Publicación Técnica No. 3. Campo Experimental Costa de Hermosillo (INIFAP). Impresos Justo a Tiempo, S.A. de C.V. México.

Pereira, M., Schneider, M., Munoz-Zanzi, C., Costa, F., Benschop, J., Hartskeerl, R., Martinez, J., Jancloes, M. and Bertherat, E. 2018. A road map for leptospirosis research and health policies based on country needs in Latin-America. Revista Panamericana de Salud Pública. 41:e131.

Petrakovsky, J., Tinao, J. and Esteves, J. 2013. Leptospirosis porcina:prevalencia serológica en establecimientos productores de la República Argentina. Revista MVZ Córdoba. 18:3282-3287.

Pinto Pda, S., Libonati, H., Penna, B. and Lilenbaum, W. 2016. A systematic review on the microscopic agglutination test seroepidemiology of bovine leptospirosis in Latin-America. Trop Anim Health Prod. 48:239-248.

Pratt, N. and Rajeev, S. 2018. Leptospira seroprevalence in animals in the Caribbean region: A systematic review. Acta tropica. 182:34-42.

Pulido-Villamarín, A., Carreño-Beltrán, G., Mercado-Reyes, M. and Ramírez-Bulla, P. 2014. Situación epidemiológica de la leptospirosis humana en Centroamérica, Suramérica y el Caribe. Universitas Scientiarum. 19:247-264.

Putz, E.J. and Nally, J.E. 2020. Investigating the Immunological and Biological Equilibrium of Reservoir Hosts and Pathogenic Leptospira: Balancing the Solution to an Acute Problem? Frontiers in Immunology. 11:2005.

Rahman, M.H.A.A., Hairon, S.M., Hamat, R.A., Jamaluddin, T.Z.M.T., Shafei, M.N., Idris, N., Osman, M., Sukeri, S., Wahab, 
Z.A. and Mohammad, W.M.Z.W. 2018. Leptospirosis health intervention module effect on Knowledge, attitude, belief, and practice among wet market Workers in Northeastern Malaysia: an intervention study. International Journal of Environmental Research and Public Health. 15:1396.

Rajapakse, S., Rodrigo, C., Handunnetti, S.M. and Fernando, S.D. 2015. Current immunological and molecular tools for leptospirosis: diagnostics, vaccine design, and biomarkers for predicting severity. Annals of Clinical Microbiology and Antimicrobials. 14:2.

Richard, S. and Oppliger, A. 2015. Zoonotic occupational diseases in forestry workers - Lyme borreliosis, tularemia and leptospirosis in Europe. Annals of Agricultural and Environmental Medicine. 22:43-50.

Rivera-Benitez, J., Rosas-Estrada, K., Pulido-Camarillo, E., de la Peña-Moctezuma, A., Castillo-Juárez, H. and RamírezMendoza, H. 2014. Serological Survey of Veterinarians to Assess the Zoonotic Potential of Three Emerging Swine Diseases in Mexico. Zoonoses and Public Health. 61:131-137.

Rodríguez, Y., Echeverría, E., Rodriguez, J., Valdés, Y., Rodriguez, I. and Obregón, A.M. 2018. Leptospira Serovars Circulating in Eastern Region of Cuba, from 2007 to 2012. Journal of Veterinary Medicine and Research.

Rodríguez-Parra, M., Bocanegra-arcía, V., Acosta-González, R., García-Oropesa, E., Bocanegra-Alonso, A. and FloresGutiérrez, G. 2009. Seropositividad a Leptospira en trabajadores de rastros de Tamaulipas. Bioquimia. 34:92.

Samsudin, S., Sakinah, S., Malina, O., Norliza, B., Noh, M., Fairuz, A., Jamaluddin, T., Hamat, R., Zahiruddin, W. and Mohd Nazri, S. 2018. Seroprevalence of leptospiral antibodies among market workers and food handlers in the central state of Malaysia. Tropical Medicine \& International Health. 23:327333.

Sanchez-Montes, S., Espinosa-Martinez, D.V., Rios-Munoz, C.A., Berzunza-Cruz, M. and Becker, I. 2015. Leptospirosis in Mexico: Epidemiology and Potential Distribution of Human Cases. PLoSOne. 10:e0133720.

Sanhueza, J.M., Heuer, C., Wilson, P.R., Benschop, J. and CollinsEmerson, J.M. 2017. Seroprevalence and Risk Factors for Leptospira Seropositivity in Beef Cattle, Sheep and Deer Farmers in New Zealand. Zoonoses Public Health. 64:370380.

Schneider, M.C., Leonel, D.G., Hamrick, P.N., Caldas, E.P.d., Velásquez, R.T., Paez, F.A.M., Arrebato, J.C.G., Gerger, A., Pereira, M.M. and Aldighieri, S. 2017. Leptospirosis in LatinAmerica: exploring the first set of regional data. RevistaPanamericana de Salud Pública. 41:e81.

Sehgal, S., Sugunan, A., Murhekar, M., Sharma, S. and Vijayachari, P. 2000. Randomized controlled trial of doxycycline prophylaxis against leptospirosis in an endemic area. International Journal of Antimicrobial Agents. 13:249-255.

Sequeira, J., Jiménez, M., Araya, L., Avalos, J. and Oviedo, M. 2016. Seroprevalencia de Leptospira spp. en ganado bovino lechero de la región Huetar Norte de Costa Rica. Revista Ciencias Veterinarias. 34:23.

Shaked, Y., Shpilberg, O., Samra, D. and Samra, Y. 1993. Leptospirosis in pregnancy and its effect on the fetus: case report and review. Clinical Infectious Diseases. 17:241-243.

Shiokawa, K., Welcome, S., Kenig, M., Lim, B. and Rajeev, S. 2019. Epidemiology of Leptospira infection in livestock species in Saint Kitts. Tropical animal health and production. 51:16451650.
Sonrier, C., Branger, C., Michel, V., Ruvoen-Clouet, N., Ganiere, J. and Andre-Fontaine, G. 2000. Evidence of cross-protection within Leptospira interrogans in an experimental model. Vaccine. 19:86-94.

Stackebrandt, E., Chertkov, O., Lapidus, A., Nolan, M., Lucas, S., Hammon, N., Deshpande, S., Cheng, J.F., Tapia, R., Goodwin, L.A., Pitluck, S., Liolios, K., Pagani, I., Ivanova, N., Mavromatis, K., Mikhailova, N., Huntemann, M., Pati, A., Chen, A., Palaniappan, K., Land, M., Pan, C., Rohde, M., Gronow, S., Goker, M., Detter, J.C., Bristow, J., Eisen, J.A., Markowitz, V., Hugenholtz, P., Woyke, T., Kyrpides, N.C. and Klenk, H.P. 2013. Genome sequence of the free-living aerobic spirochete Turneriella parva type strain $(\mathrm{H}(\mathrm{T}))$, and emendation of the species Turneriella parva. Standards in Genomic Sciences. 8:228-238.

Suepaul, S., Carrington, C., Campbell, M., Borde, G. and Adesiyun, A. 2010. Serovars of Leptospira isolated from dogs and rodents. Epidemiology \& Infection. 138:1059-1070.

Taddei, S., Moreno, G., Cabassi, C.S., Schiano, E., Spadini, C. and Cavirani, S. 2021. Leptospira Seroprevalence in Colombian Dairy Herds. Animals. 11:785.

Tan, W.L., Soelar, S.A., Mohd Suan, M.A., Hussin, N., Cheah, W.K., Verasahib, K. and Goh, P.P. 2016. Leptospirosis Incidence and Mortality in Malaysia. Southeast Asian J Trop Med Public Health. 47:434-440.

Thibeaux, R., Geroult, S., Benezech, C., Chabaud, S., SoupeGilbert, M.E., Girault, D., Bierque, E. and Goarant, C. 2017. Seeking the environmental source of Leptospirosis reveals durable bacterial viability in river soils. PLoS Neglected Tropical Diseases. 11:e0005414.

Thiermann, A.B. 1982. Experimental leptospiral infections in pregnant cattle with organisms of the Hebdomadis serogroup. American Journal of Veterinary Research. 43:780784.

Vado-Solís, I.A., Cárdenas-Marrufo, M.F., Pérez-Osorio, C.E., Jiménez-Delgadillo, B., Arias-León, J.J. and Peniche-Lara, F. 2014. Leptospirosis: una enfermedad ocupacional en trabajadores que conviven con bovinos seropositivos en el estado de Yucatán. Ciencias Humanismo Salud. 1:4-13.

Valença, R., Mota, R., Castro, V., Anderlini, G., Pinheiro Junior, J., Brandespim, D., Valença, S. and Guerra, M. 2013. Prevalence and risk factors associated with Leptospira spp. infection in technified swine farms in the state of Alagoas, Brazil risk factors associated with Leptospira spp. in swine farms. Transboundary and emerging diseases. 60:79-86.

Velasco-Castrejón, O., Rivas-Sánchez, B., Sánchez-Spíndola, M.E., Soriano, J., Rivera-Reyes, H.H. and Sebles, V.G. 2009. Leptospirosis crónica en México. Revista Mexicana de Patología Clínica y Medicina de Laboratorio. 56:157-167.

Vieira, A.S., Pinto, P.S. and Lilenbaum, W. 2018. A systematic review of leptospirosis on wild animals in Latin-America. Tropical animal health and production. 50:229-238.

Vincent AT, Schiettekatte O, Goarant C, Neela VK, Bernet E, Thibeaux R, et al. (2019) Revisiting the taxonomy and evolution of pathogenicity of the genus Leptospira through the prism of genomics. PLoS Negl Trop Dis 13(5):e0007270. https://doi.org/10.1371/journal.pntd.0007270

Vinod Kumar, K., Lall, C., Vimal Raj, R., Vedhagiri, K. and Vijayachari, P. 2016. Molecular detection of pathogenic leptospiral protein encoding gene (lipL32) in environmental aquatic biofilms. Letters in applied microbiology. 62:311-315.

Volumen XXIII, Número 3 
Waggoner, J.J. and Pinsky, B.A. 2016. Molecular diagnostics for human leptospirosis. Current Opinion in Infectious Diseases. 29:440-445.

WHO. 2002. Occupational health:a manual for primary health care workers. No. WHO-EM/OCH/85/E/L. World Health Organization Regional Office for the Eastern Mediterranean, Cairo, Egypt.

WHO. 2009. Leptospirosis Situation in the WHO South-East Asia Region. World Health Organization Regional office for South-East Asia. 7:2011.

Wynwood, S.J., Graham, G.C., Weier, S.L., Collet, T.A., McKay, D.B. and Craig, S.B. 2014. Leptospirosis from water sources. Pathogens and Global Health. 108:334-338.

Yasuda, P.H., Steigerwalt, A.G., Sulzer, K.R., Kaufmann, A.F., Rogers, F. and Brenner, D.J. 1987. Deoxyribonucleic acid relatedness between serogroups and serovars in the family Leptospiraceae with proposals for seven new Leptospira species. International Journal of Systematic and Evolutionary Microbiology. 37:407-415.
Yescas-Benitez, J.E., Rivero-Perez, N., Montiel-Díaz, H.E., Valladares-Carranza, B., Pelaez-Acero, A., Morales-Ubaldo, A.L. and Zaragoza-Bastida, A. 2020. ComportamientoEpidemiológico de Leptospirosis en México durante periodo 2012-2018. Revista Salud Pública. 22:1-5.

Zárate-Martínez, J., Rosete-Fernández, J., Ríos-Utrera, A., Barradas-Piña, F. and Olazarán-Jenkins, S. 2015. Prevalence of leptospirosis and its relationship with pregnancy rate in cattle from the central zone of Veracruz. NovaScientia. 7:202-217.

Zavala-Velázquez, J.E., Vado-Solís, I.A., Rodríguez-Félix, M.E., Rodríguez-Angulo, E.M., Barrera-Pérez, M.A. and GuzmanMarín, E.d.S. 1998. Leptospirosis anictérica en un brote epidémico de dengue en la Península de Yucatán. Revista Biomedica. 9:78-83. 